\title{
THE IMPLEMENTATION OF OECD CORPORATE GOVERNANCE PRINCIPLES IN NIGERIA: EVIDENCE FROM STAKEHOLDERS' PERSPECTIVES
}

\author{
OLAYEMI SIMON-OKE, OLUYEMI OLOGUNWA, TAJUDEEN EGBETUNDE
}

\begin{abstract}
:
This study investigates the stakeholders' perspectives on the implementation of Organization for Economic Cooperation and Development (OECD) corporate governance principles in Nigeria. The study adopted an ex-post research design with a structured questionnaire to elicit information from the respondents. The descriptive statistical method was also considered as analytical techniques. Findings revealed that shareholders in Nigerian firms have the right to participate in profits of the firm; they have the right to vote in general meetings and also have the right to obtain information about voting rights before purchase of shares. However, the study found that the details about the capital structure, financial and operating reports of firms were not fully disclosed. It was also discovered from the study that ownership transfer among shareholders was poorly facilitated, with minority shareholders not fairly treated. The study concludes that board of directors usually takes the interest of shareholders' more important than the stakeholders interest in the firms. It was however suggested that corporate governance framework in Nigeria should recognize the rights of stakeholders established by law or through mutual agreements; and encourage wealth creation and employment opportunities for sound financial sustainability of corporate firms.
\end{abstract}

\section{Keywords:}

Corporate Governance, OECD Principles, Stakeholders, Firms' Performance and Nigeria

JEL Classification: M14, D21, L60

\section{Authors:}

OLAYEMI SIMON-OKE, Federal University of Technology, Nigeria, Email: oosimon-oke@futa.edu.ng OLUYEMI OLOGUNWA, Federal University of Technology,Akure, Nigeria, Email: opologunwa@futa.edu.ng TAJUDEEN EGBETUNDE, Federal University of Technology,Akure, Nigeria, Email: tegbetunde@futa.edu.ng

\section{Citation:}

OLAYEMI SIMON-OKE, OLUYEMI OLOGUNWA, TAJUDEEN EGBETUNDE (2019). The Implementation of OECD Corporate Governance Principles in Nigeria: Evidence from Stakeholders' Perspectives. International Journal of Business and Management, Vol. VII(1), pp. 87-103., 10.20472/BM.2019.7.1.007 


\section{Introduction}

Corporate governance is the set of processes, customs, policies, laws, and institutions affecting the way a corporation (or company) is directed, administered or controlled (OECD, 2010). Corporate governance comprises the long-term management and oversight of the company in accordance with the principles of responsibility and transparency, Organization for Economic Cooperation and Development (OECD, 2010). The implementation of OECD Principles of Corporate Governance enables effective monitoring, helps firms attract investment, raises funds with low capital cost, generates long-term economic values and enhance firm performance (Sengur, 2011).Corporate governance distributes the rights and responsibilities among the various participants in a company, such as the board of directors, the shareholders and other stakeholders. It ensures that rules and procedures for making decisions regarding corporate affairs are clear (Foliage, 2011).

The stakeholder theory also plays an essential role in explaining governance structures because companies are made to aware of all stakeholders rather than only the shareholders (Freeman 1984). Good governance has become essential for improving firm performance, ensuring investors' rights and encouraging economic development (Roman and Roundtree, 2010). This view is consistent with Ogbulu and Emini (2012) that effective corporate governance generalizes powers and creates room for checks and balances which most times ensures that managers invest in positive net present value projects thus helping the relationship between management and shareholders to be characterized by transparency and fairness.

In Nigeria, the code of best practices was introduced by the Securities and Exchange Commission (SEC) and the corporate affairs commission (CAC) in investment and security act 2003 . This code is voluntary and is designed to entrench good business practices and standards for board of directors, auditors, CEOs of listed firms. With special reference to Nigeria, all the existing codes and laws are entrusted in the hands of the Corporate Affairs Commission (CAC), Security and Exchange Commission (SEC) and Central Bank of Nigeria (CBN) with the responsibility of regulating corporate governance.

This is also expected to reflects some of the key elements in OECD and other global codes, which includes Separating the roles of the Chief Executive Officer (CEO) from those of the board chairman, prescribing the existence of non-executive and executive directors on the board, Improving the quality and performance of board membership and introducing transparency, due process and disclosure requirements among others (Wilson, 2006).

Many international organizations developed guidelines as the code of conduct for corporate governance (Aguilera and Cuervo-Cazurra, 2009). These guidelines serve as corporate governance principles which consist of elements such as legislation, regulation, voluntary commitments and business practices (Okpara, 2011). However, the OECD (2004) opined that the content and structure of this framework may need to be adjusted based on the unique situation of each country, including changes in business circumstances, history and customs. The OECD Principles was also set up with four fundamental concepts in mind: responsibility, accountability, fairness and transparency (Harabi, 2007). 
These Principles allow for diversity of rules and regulations that are primarily concerned with listed firms. Clearly, less developed countries need to adopt an effective corporate governance principle to solve these problems and encourage new practices for implementing the different features of corporate governance (Mulili and Wong, 2011). Against this background, this paper examined the stakeholders' perceptions on the implementation of corporate governance principles in ensuring an improved corporate governance in Nigeria, as spelt out by the Organization for Economic Cooperation and development (OECD).

\section{Literature Review}

\subsection{Conceptualizing Corporate Governance}

In any organization, corporate governance is one of the key factors that determine the health of the system and its ability to survive shocks. The health of the organization depends on the underlying soundness of its individual components and the connections between them (Wilson 2006). According to Morck, Shleifer and Vishny (1989), among the main factors that support the stability of any country's financial system are: good corporate governance; effective marketing discipline; strong and prudential regulation and supervision; accurate and reliable accounting and financial reporting systems; a sound disclosure regimes and an appropriate savings deposit protection system.

In 2000, the OECD Principles of Corporate Governance became one of the 12 core standards of global financial stability, and they are now used as a benchmark by international financial institutions (Cornford, 2004). The OECD was established based on Article 1 of the Convention signed in Paris on 14 December 1960, and it came into force on 30th September, 1961. The key function of the OECD is to provide management consultations to member governments. The OECD Principles of Corporate Governance was revised in 2004 to assist governments in their effort to evaluate and improve legal, institutional and regulatory frameworks for corporate governance in their respective countries.

Although cultural and institutional differences exist between countries (Jesover and Kirkpatrick, 2005). In 2006, the OECD issued the methodology for assessing the implementation of the OECD Principles on Corporate Governance. The principles cover five areas: the rights of shareholders and key ownership functions, the equitable treatment of shareholders, the role of stakeholders in corporate governance disclosure and transparency, and the responsibilities of the board.

\subsection{Organization for Economic Cooperation and Development (OECD) Principles of}

\section{Corporate Governance}

\section{(i) Rights of shareholders and key ownership functions}

The launching of good corporate governance controls prevents shareholders from gaining more control in countries where investor protection is low; this is reflected in measures of performance and market valuation, (Doidge, Karolyi and Stulz, 2004). Klapper and Love (2004) suggest that good corporate governance practices are more essential in countries with inefficient enforcement and weak shareholder rights. They further suggested the adoption of good corporate governance practices for firms especially in countries with weak legal systems. 
Companies should also ensure shareholders' rights to participate and vote in general shareholders meetings and select members of the board, while shareholders should also be provided with information that is relevant and material about the firm on a timely and regular basis through notice of annual general meeting (king and Wen, 2011; Karpoff, Malatesta and Walkling, 1996; Giilan and Starks, 2000).

Murphy and Topyan (2005) in their own submission stated that the most significant feature of corporate governance is to protect the minority shareholders who are not active, compared to the large and active shareholders while the areas of shareholder rights remains the main aspects of a sound corporate governance system (Mallin and Melis, 2012)

\section{(ii)Equitable Treatment of Shareholders}

The corporate governance framework should also include the equitable treatment of all shareholders, including minority and foreign shareholders. All shareholders should have the opportunity to obtain effective redress for the violation of their rights (OECD, 2004). The equitable treatment of all shareholders demands transparency with respect to the distribution of voting rights and the ways that voting rights are exercised. This principle also requires the disclosure of any material interests that management and board members have in transactions or matters affecting the corporation (Nestor and Jesover, 2000).

In the same all shareholders should have the same voting rights, they should be able to obtain sufficient information about their voting rights before they purchase shares (Shanikat and Abbadi, 2011). Shareholders should have the opportunity to receive effective redress for violations of their rights, while minority shareholders should be protected from abusive actions by, or in the interest of, controlling shareholders, whether directly or indirectly (Cheung, 2011). Further, more internal control systems also need to be established to prohibit the use of inside information (Givoly and Palmon, 1985) and the ability of the firm to protect the minority shareholders' rights could be enhanced by strong implementation of corporate governance, (Chhaochharia and Laeven, 2009).

\section{(iii)Role of stakeholders}

The corporate governance framework should also recognise the rights of stakeholders established by law or through mutual agreements and encourage active cooperation between corporations and stakeholders in creating wealth, jobs and the sustainability of financially sound enterprises. The stakeholders' principle focuses on the relationship between the corporation and stakeholders in creating value (OECD,2004), This principle should cover the role of stakeholders to reflect the interaction with, and treatment of, stakeholders such as employees, creditors, suppliers, shareholders and the environment (Cheung, 2011).

Also, management has a responsibility to ensure that shareholders receive a fair return on their investments; it also has a responsibility to all stakeholders and should manage and alleviate the conflicts of interest that may exist between the firm and its stakeholders (Prugsamatz, 2010). Directors in Corporate firms should also be in a position of trust and manage the company in a way that creates long-term sustainable value, while simultaneously considering their relationships with wider stakeholder groups such as employees, customers, suppliers and communities as a whole which also have direct and indirect effects on firm performance (Bernian, 1999). 


\section{(iv)Disclosure and transparency}

This involves corporate governance framework, which ensure timely and accurate disclosure on all material matters regarding the corporation, including the financial situation, performance, ownership and governance of the company (OECD, 2004). A company information disclosure that consists of corporate performance disclosure and financial accounting disclosure is the principal means through which companies become transparent to all stakeholders (Gill, Vijay and Jha, 2009). The disclosure and transparency should also show that the existence of policies and instructions are in line with the laws and a regulation relating to the company and the nature of the business (Shanikat and Abbadi, 2011).

Therefore, transparency and disclosure are significant and fundamental features of corporate governance, which means that good disclosure practice is a form of good corporate governance. This is because the market might expect more serious information asymmetry problems if a company have poor information disclosure and transparency practices (Chen, 2007).

\section{(v)Responsibilities of the Board of Directors}

The main responsibilities of the board are to make decisions on the business operations of the company and to manage the activities of the directors (Jang and Kim, 2001). As part of the strategic guidance framework for the company, the board of directors should be a well-functioning and effective board because it is an important aspect in enhancing corporate governance in market systems (Solomon, 2007; DC Andres, Azofra and Lopez, 2005). Equally, the board of directors is responsible for formulating policies and strategies and supervising the operations of the company (Ahmed and Gabor, 2012).

In addition, board members should direct and control the affairs of the company, act on a fully informed basis and in good faith with the best interests of the shareholders and all other stakeholders, and ensure compliance with applicable laws by management, shareholders and stakeholders (Awotundun, Kehinde and Somoye, 2011). This implies that the board acts as a mediator between the principal and the agents to ensure that capital is directed to the right objective.

\section{Methodology}

This study adopted an ex post facto research design, a quasi-experimental study in nature. The sampling frame consists of the 180 listed firms on the Nigerian Stock Exchange with a total capitalization of N10.16 Trillion. The study employed a multistage sampling technique. At the first stage, the listed firms' were stratified into sectors. At the second stage, a purposive sampling technique, which is a nonprobability sampling technique, based on the specific purpose and appropriate characteristics required of samples were used, and as previously adopted in similar studies across Countries (zikmand, 2010; khaled , 2014).

The criteria that was employed for the purposive sampling of fifty (50) listed firms includes, firm accessibility, turnover rate, profit margin and year of existence, while firms' for which there are no, annual reports of corporate governance data, as well as foreign firms were excluded from the study sample. This is because foreign firms do not follow Nigerian code of corporate governance though they are listed. 
The study was designed to survey different groups of stakeholders identified as respondent who provided the required data from the sampled firms'. The stakeholder groups are the managers /CEOs, member of the board, internal auditor and accountants. This group of people were believed to be a part, or process of corporate governance and financial operation of any listed companies. The main reason for choosing this group is based on previous research in different countries that had identified these participants as the most relevant groups in relation to the issue of corporate governance (Gridiron and Scow, 2002).

However the study sample covered the period between 2008 and 2017 and the rationale for the choice of this period is that corporate governance guidelines was introduced in 2003 and modified in 2008 as a guide for corporate governance variables. This is assumed a suitable time period, for firms' to have shown some level of changes in the adoption of corporate governance practices.

The method of analysis adopted for the study was purely descriptive with the use of frequency counts, percentages, as well as mean deviations. The descriptive statistics captured the respondents characteristics and their perceptions on the the rights of shareholders and key ownership functions, the equitable treatment of shareholders, the role of stakeholders in corporate governance, as well as disclosure and transparency, and the responsibilities of the board.

\section{Results and Discussion}

This section investigates the descriptive analysis of stakeholders' perspectives on the implementations of corporate governance principles, which include the rights of shareholders, equitable treatment of shareholders, role of stakeholders in corporate governance, disclosure and transparency, and the responsibility of board of directors. Stakeholders' responses on the related issues on corporate governance principles were processed through a 5-points Likert rating scale ranging from 1 (strongly disagree) to 5 (strongly agree).

\subsection{Perception of stakeholders' on the implementation of OECD Corporate Governance principles in Nigeria}

\subsubsection{The Perceived Rights of Shareholders}

The result in Table 1, with the mean scores of 4.39, 4.38, 4.30, 4.28 and 4.22 revealed that; the respondents strongly agreed that shareholders have the right to vote in general meetings, they have the right to participate in company's profits, and they also have the right to adequate and timely information about firm's meetings. They have the right to obtain information related to the firms regularly and the right to vote in elections and remove members of the board of directors respectively. The result further showed that respondents also agreed that Shareholders have the right to discuss the external auditor's report at the Annual General Meeting and details about the capital structure of firm was disclosed to shareholders (with a mean value of 4.17 and 3.83). The result however, strongly disagreed that ownership transfer among shareholders was facilitated judging from the mean value of 1.7.

This result also indicates that majority of the respondents agreed at varying degrees; and with a grand mean of 3.91 on the implementation of the principle of the rights of shareholders in Nigeria The implication is that shareholders of firms in Nigeria are 
enjoying the implementation of all the principles of the rights of shareholders with the exception of the right of ownership transfer among shareholders, which was poorly facilitated. This result opposes the findings of Cheung (2011) that shareholders' rights should be protected including the ownership right. However, the result agrees with King and Wen (2011) that companies should ensure that shareholders select members of the board by participating and voting in general meetings.

Table 1: Responses on the implementation of Shareholders Rights

\begin{tabular}{|c|c|c|c|c|c|c|c|c|c|}
\hline Statement & $\begin{array}{l}\text { Strongly } \\
\text { disagree }\end{array}$ & Disagree & $\begin{array}{l}\text { Uncert } \\
\text { ain }\end{array}$ & Agree & $\begin{array}{l}\text { Strongl } \\
\text { y agree }\end{array}$ & $\begin{array}{l}\text { Subtota } \\
\text { I }\end{array}$ & Mean & $\begin{array}{l}\text { Ran } \\
\mathbf{k}\end{array}$ & $\begin{array}{l}\text { Remar } \\
\mathbf{k}\end{array}$ \\
\hline $\begin{array}{l}\text { a1. Ownership } \\
\text { transfer among } \\
\text { shareholders is } \\
\text { facilitated }\end{array}$ & 56 & 32 & 6 & 5 & 3 & 102 & 1.7 & 8 & $\begin{array}{l}\text { Strongl } \\
\mathrm{y} \\
\text { disagre } \\
\mathrm{e}\end{array}$ \\
\hline $\begin{array}{l}\text { a2. Shareholders } \\
\text { have the right to } \\
\text { participate in firms } \\
\text { profits }\end{array}$ & 0 & 0 & 0 & 63 & 39 & 102 & 4.38 & 2 & $\begin{array}{l}\text { Strongl } \\
\text { y agree }\end{array}$ \\
\hline $\begin{array}{l}\text { a3. Shareholders } \\
\text { have the right to } \\
\text { obtain information } \\
\text { related to the firms } \\
\text { regularly }\end{array}$ & 0 & 0 & 0 & 73 & 29 & 102 & 4.28 & 4 & $\begin{array}{l}\text { Strongl } \\
\text { y agree }\end{array}$ \\
\hline $\begin{array}{l}\text { a4. Shareholders } \\
\text { have the right to } \\
\text { vote in general } \\
\text { meetings }\end{array}$ & 0 & 0 & 1 & 60 & 41 & 102 & 4.39 & 1 & $\begin{array}{l}\text { Strongl } \\
\text { y agree }\end{array}$ \\
\hline $\begin{array}{l}\text { a5. Shareholders } \\
\text { are able to vote in } \\
\text { elections and } \\
\text { remove members of } \\
\text { the board of } \\
\text { directors }\end{array}$ & 0 & 1 & 9 & 59 & 33 & 102 & 4.22 & 5 & $\begin{array}{l}\text { Strongl } \\
\text { y agree }\end{array}$ \\
\hline $\begin{array}{l}\text { a6. Shareholders } \\
\text { are provided with } \\
\text { adequate and timely } \\
\text { information about } \\
\text { firms meetings }\end{array}$ & 0 & 2 & 7 & 51 & 42 & 102 & 4.30 & 3 & $\begin{array}{l}\text { Strongl } \\
\text { y agree }\end{array}$ \\
\hline $\begin{array}{l}\text { a7. Shareholders } \\
\text { have the right to } \\
\text { discuss the external } \\
\text { auditor's report at } \\
\text { the Annual General } \\
\text { Meeting }\end{array}$ & 1 & 6 & 7 & 49 & 39 & 102 & 4.17 & 6 & Agree \\
\hline $\begin{array}{l}\text { a8. Details about } \\
\text { the capital structure } \\
\text { of your firm is } \\
\text { disclosed to } \\
\text { shareholders }\end{array}$ & 1 & 17 & 13 & 38 & 33 & 102 & 3.83 & 7 & Agree \\
\hline Grand Mean & & & & & & & 3.91 & & Agree \\
\hline
\end{tabular}

Source: Field Survey, (2017) .

Mean Rank: Strongly agree $=4.21-5.00$, Agree $=3.41-4.20$, Uncertain $=2.61-3.4$, Disagree $=1.81-2.6$, strongly disagree $=1-1.8$ 


\subsubsection{Equitable Treatment Rights of Shareholders}

In Table 2, the respondents agreed with the grand mean of 3.74, which confirmed the implementation of the equitable treatment rights of shareholders in Nigerian firms. It was also discovered that the respondents agreed that shareholders enjoyed all the equitable treatment rights except where the respondents were uncertain whether there are means to remove the obstacles of cross-border voting; and if minority shareholders are fairly treated in the firms. Notwithstanding, the result agrees with previous research of Shanikat and Abbadi, (2011), on one of the equitable treatment rights of the shareholders that they should be able to obtain sufficient information about their voting rights before the purchase of shares. The implication is that, although shareholders have the right to obtain information about voting rights before the purchase of shares but minority shareholders were fairly treated as indicated by the mean value (3.11) falling within the uncertainty range. This is not in agreement with the findings of Cheung (2011), that minority shareholders should be protected from abusive actions by, or in the direct or indirect interest of controlling shareholders.

Table 2: Responses on the implementation of Equitable Treatment Rights of Shareholders

\begin{tabular}{|c|c|c|c|c|c|c|c|c|c|}
\hline Statement & 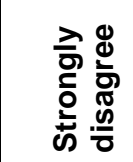 & 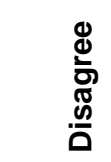 & $\begin{array}{l}\frac{.}{\pi} \\
\frac{t}{d} \\
\frac{0}{5} \\
\frac{0}{5}\end{array}$ & 这 & 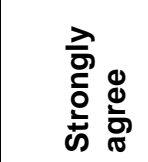 & $\begin{array}{l}\bar{\pi} \\
0 \\
0 \\
\frac{0}{5} \\
\omega\end{array}$ & 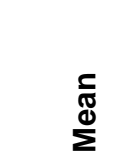 & 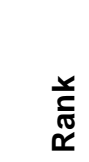 & 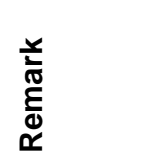 \\
\hline $\begin{array}{l}\text { b1 Minority shareholders } \\
\text { are fairly treated }\end{array}$ & 11 & 24 & 18 & 41 & 8 & 102 & 3.11 & 6 & $\begin{array}{l}\text { Undecid } \\
\text { ed }\end{array}$ \\
\hline $\begin{array}{l}\text { b2. Shareholders have } \\
\text { the right to obtain } \\
\text { information about voting } \\
\text { rights before they } \\
\text { purchase shares }\end{array}$ & 0 & 0 & 8 & 83 & 11 & 102 & 4.03 & 1 & Agree \\
\hline $\begin{array}{l}\text { b3. Processes and } \\
\text { procedures for general } \\
\text { shareholders' meetings } \\
\text { allow for equitable } \\
\text { treatment of all } \\
\text { shareholders }\end{array}$ & 0 & 0 & 18 & 71 & 13 & 102 & 3.95 & 3 & Agree \\
\hline $\begin{array}{lr}\text { b4. } & \text { Minority } \\
\text { shareholders } & \text { are } \\
\text { protected from } & \text { insider } \\
\text { trading } & \end{array}$ & 0 & 1 & 26 & 53 & 22 & 102 & 3.94 & 4 & Agree \\
\hline $\begin{array}{l}\text { b5. There are means to } \\
\text { remove the obstacles of } \\
\text { cross-border voting }\end{array}$ & 13 & 11 & 12 & 54 & 12 & 102 & 3.40 & 5 & $\begin{array}{l}\text { Undecid } \\
\text { ed }\end{array}$ \\
\hline $\begin{array}{l}\text { b6. Board members and } \\
\text { key executives disclose } \\
\text { material interests in any } \\
\text { transaction or matter } \\
\text { directly affecting the } \\
\text { firm }\end{array}$ & 0 & 1 & 25 & 50 & 26 & 102 & 3.99 & 2 & Agree \\
\hline Grand Mean & & & & & & & 3.74 & & Agree \\
\hline
\end{tabular}

Source: Field Survey, (2017) .

Mean Rank: Strongly agree $=4.21-5.00$, Agree $=3.41-4.20$, Uncertain $=2.61-3.4$, Disagree $=1.81-2.6$, strongly disagree $=1=1.8$ 


\subsubsection{The Role of Stakeholders}

In Table 3, respondents strongly agreed that stakeholders were permitted to obtain sufficient and reliable information on a timely basis as well the opportunity to obtain effective redress for violation of their rights with the mean value of 4.25 and 4.24 respectively. The respondents also agreed that stakeholders' roles as established by law were respected by firms with a mean value of 4.19 , while the role of Performanceenhancing mechanisms for employee participation was also permitted to operate and develop in the firms, showing mean value of 4.02. The result further showed the agreement of respondents on stakeholders' role of recognizing effective corporate governance framework to enforce creditor rights and also to have access to freely communicate their concerns about illegal or unethical practices to the board of directors, with the mean value of 3.95 and 3.85 respectively.

The result established that the majority of the respondents agreed to the fact that the established roles of stakeholders by law were recognized and operated in Nigerian firms, with an overall mean score of 4.08. This result agrees with OECD, (2004) that corporate governance ensures the recognition and protection of roles and rights of Stakeholders.

Table 3: Responses on the established Role of Stakeholders

\begin{tabular}{|l|l|l|l|l|l|l|l|l|l|}
\hline Statement & & & & & & & & & \\
\end{tabular}




\begin{tabular}{|l|l|l|l|l|l|l|l|l|l|}
$\begin{array}{l}\text { governance framework } \\
\text { enforces creditor rights }\end{array}$ & & & & & 20 & & & & \\
\hline Grand Mean & & & & & & & & & Agree \\
\hline
\end{tabular}

Source: Field Survey, (2017)

Mean Rank: Strongly agree $=4.21-5.00$, Agree $=3.41-4.20$, Uncertain $=2.61-3.4$, Disagree $=1.81$ 2.6, strongly disagree $=1=1.8$

\subsubsection{The Principles of Disclosure and Transparency}

Table 4, revealed the responses on the implementation of the disclosure and transparent principles. The respondents strongly agreed that an annual audit of firms were conducted by an independent auditor with a mean of 4.27 . The majority of the respondents also agreed with the implementation of all the principles of disclosure and transparency in corporate firms (mean values; 4.17, 4.09, 4.09 3.98, 3.55 and 3.41); with the exception of (uncertain mean value of 3.39) the disclosure of major share ownership.

Although, the result showed that annual audits of the firms were conducted and made public by an independent auditor; but the financial and operating reports of the firms were not fully disclosed and thereby violating the established companies' laws; as indicated by the lower limit range of agree mean value of 3.41 in Table 4. This contradicts the existing studies of Shanika and Abbadi, (2011) that the disclosure and transparency should show the existence of policies and instructions in line with the laws and regulation relating to the company and the nature of the business. 
Table 4: Responses on the Implementation of the Principles of Disclosure and Transparency

\begin{tabular}{|c|c|c|c|c|c|c|c|c|c|}
\hline 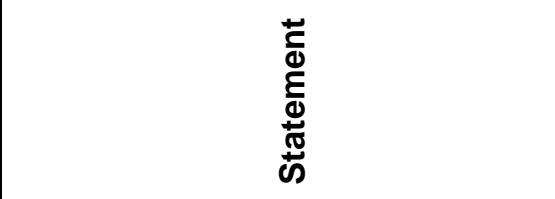 & 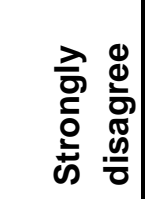 & 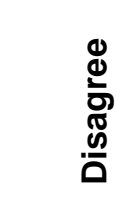 & 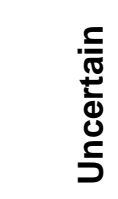 & 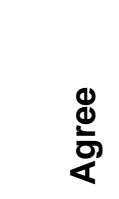 & 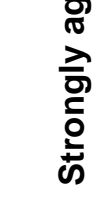 & $\begin{array}{l}\bar{\pi} \\
\frac{\pi}{0} \\
\frac{0}{2} \\
\omega\end{array}$ & 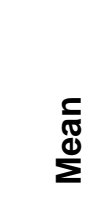 & 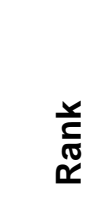 & 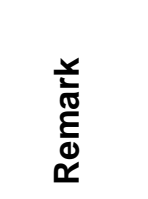 \\
\hline $\begin{array}{l}\text { d1. The financial and operating } \\
\text { results of the firm are disclosed }\end{array}$ & 2 & 34 & 1 & 50 & 15 & 102 & 3.41 & 8 & Agree \\
\hline $\begin{array}{l}\text { d2. The objectives of the firm are } \\
\text { disclosed }\end{array}$ & 1 & 3 & 4 & 72 & 22 & 102 & 4.09 & 3 & Agree \\
\hline $\begin{array}{l}\text { d3. Major share ownership is } \\
\text { disclosed }\end{array}$ & 4 & 26 & 9 & 52 & 11 & 102 & 3.39 & 9 & $\begin{array}{l}\text { Uncerta } \\
\text { in }\end{array}$ \\
\hline $\begin{array}{l}\text { d4. Foreseeable risk factors are } \\
\text { disclosed }\end{array}$ & 4 & 24 & 11 & 38 & 25 & 102 & 3.55 & 6 & Agree \\
\hline $\begin{array}{l}\text { d5. Remuneration of board } \\
\text { members and key executives is } \\
\text { disclosed }\end{array}$ & 3 & 21 & 20 & 35 & 23 & 102 & 3.53 & 7 & Agree \\
\hline $\begin{array}{l}\text { d6. Issues regarding employees } \\
\text { and other stakeholders, such as } \\
\text { programs for human resource } \\
\text { development and training, are } \\
\text { disclosed }\end{array}$ & 1 & 2 & 4 & 67 & 28 & 102 & 4.17 & 2 & Agree \\
\hline $\begin{array}{l}\text { d7. An annual audit of the } \\
\text { company is conducted by an } \\
\text { independent auditor }\end{array}$ & 1 & 1 & 0 & 67 & 33 & 102 & 4.27 & 1 & $\begin{array}{l}\text { Strongl } \\
\text { y Agree }\end{array}$ \\
\hline $\begin{array}{l}\text { d8. Information is prepared and } \\
\text { disclosed in accordance with } \\
\text { International } \\
\text { Standards }\end{array}$ & 0 & 0 & 13 & 71 & 18 & 102 & 4.09 & 4 & Agree \\
\hline $\begin{array}{l}\text { d9. Channels for the } \\
\text { dissemination of information on a } \\
\text { timely basis to relevant users are } \\
\text { provided }\end{array}$ & 0 & 0 & 16 & 72 & 14 & 102 & 3.98 & 5 & Agree \\
\hline Grand Mean & & & & & & & 3.83 & & Agree \\
\hline
\end{tabular}

Source: Field Survey, (2017) .

Mean Rank: Strongly agree $=4.21-5.00$, Agree $=3.41-4.20$, Uncertain $=2.61-3.4$, Disagree $=1.81-2.6$, strongly disagree $=1=1.8$

\subsubsection{Responsibilities of the Board Directors}

The respondents' perspectives on the level of adherence to OECD established responsibilities of board of directors' of corporate firms in Nigeria were considered in Table 5.The respondents were all in agreed position with a grand mean of 4.03 , that board of directors of corporate firms in Nigeria performed their responsibilities in accordance with OECD principles. 
Meanwhile, the respondents agreed with the corresponding mean values $(4.15,4.14$, $3.86,3.45$, and 3.43) that the board monitors and manages potential conflicts of interest of management, board members and shareholders; board members act in the best interests of the firm and the shareholders; board members are provided with accurate relevant information about the firm; board members are able to devote sufficient time to their responsibilities and also fairly takes stakeholders' interests into account.

Parts of the perceived responsibilities of the board of directors were in agreement with the studies of Al-Tamimi and Charif (2012), which opined that the board of directors considered the importance of its relationship with shareholders and develop a good relationship with other stakeholders.

However, this result implies that board of directors takes the interest of shareholders' more important than the stakeholders interest in the firms as indicated in Table 5, where the mean value of 4,14 representing the shareholders' interests is higher than the mean value of 3.43 , which represent the stakeholders' interests.

Table 5: Responses on the Established Responsibilities of Board Directors

\begin{tabular}{|c|c|c|c|c|c|c|c|c|c|}
\hline $\begin{array}{l}\frac{\sum}{\Phi} \\
\frac{E}{\Phi} \\
\frac{\pi}{\pi} \\
\omega\end{array}$ & 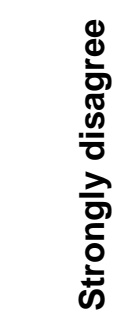 & 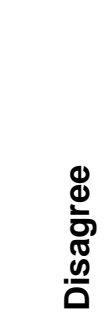 & 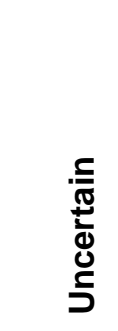 & ষ্ঠ & 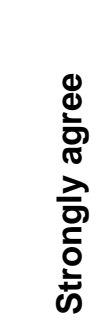 & $\begin{array}{l}\bar{\pi} \\
\frac{0}{0} \\
\frac{0}{0} \\
\text { œ }\end{array}$ & 离 & 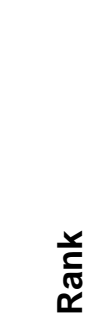 & 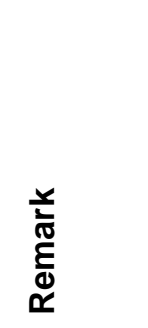 \\
\hline $\begin{array}{l}\text { e1. Board members act in the } \\
\text { best interests of the firm and the } \\
\text { shareholders }\end{array}$ & 1 & 6 & 1 & 64 & 30 & 102 & 4.14 & 6 & Agree \\
\hline $\begin{array}{llr}\text { e2. The } & \text { board takes } \\
\text { stakeholders' } & \text { interests } & \text { into } \\
\text { account } & & \end{array}$ & 11 & 13 & 25 & 27 & 26 & 102 & 3.43 & 9 & Agree \\
\hline $\begin{array}{l}\text { e3. The board monitors the } \\
\text { effectiveness of the firm's } \\
\text { governance practices }\end{array}$ & 0 & 0 & 1 & 67 & 34 & 102 & 4.32 & 2 & $\begin{array}{l}\text { Strongl } \\
\text { y Agree }\end{array}$ \\
\hline $\begin{array}{l}\text { e4. The board of directors } \\
\text { elects, monitors and replaces } \\
\text { executives when necessary }\end{array}$ & 0 & 0 & 2 & 63 & 37 & 102 & 4.34 & 1 & $\begin{array}{l}\text { Strongl } \\
\text { y Agree }\end{array}$ \\
\hline $\begin{array}{l}\text { e5. The board monitors and } \\
\text { manages potential conflicts of } \\
\text { interest of management, board } \\
\text { members and shareholders }\end{array}$ & 0 & 0 & 3 & 81 & 18 & 102 & 4.15 & 5 & Agree \\
\hline $\begin{array}{l}\text { e6. The board supervises the } \\
\text { process of disclosure and } \\
\text { communication }\end{array}$ & 0 & 0 & 10 & 58 & 34 & 102 & 4.24 & 4 & $\begin{array}{l}\text { Strongl } \\
\text { y Agree }\end{array}$ \\
\hline $\begin{array}{l}\text { e7. Board members are } \\
\text { provided with accurate relevant } \\
\text { information about the firm }\end{array}$ & 0 & 18 & 3 & 56 & 25 & 102 & 3.86 & 7 & Agree \\
\hline $\begin{array}{l}\text { e8. The board approve a } \\
\text { strategic plan for the firm }\end{array}$ & 0 & 0 & 0 & 70 & 32 & 102 & 4.31 & 3 & $\begin{array}{l}\text { Strongl } \\
\text { y Agree }\end{array}$ \\
\hline
\end{tabular}




\begin{tabular}{|l|l|l|l|l|l|l|l|l|l|}
$\begin{array}{l}\text { e9. Board members are able to } \\
\text { devote sufficient time to their } \\
\text { responsibilities }\end{array}$ & 0 & 18 & 34 & 36 & 14 & 102 & 3.45 & 8 & Agree \\
\hline Grand Mean & & & & & & & & & Agree \\
\hline
\end{tabular}

Source: Field Survey, (2017) .

Mean Rank: Strongly agree $=4.21-5.00$, Agree $=3.41-4.20$, Uncertain $=2.61-3.4$, Disagree $=1.81-2.6$, strongly disagree $=1=1.8$

\section{Conclusion}

The study investigated the stakeholders' perspectives on the implementation of corporate governance principles in Nigeria. Findings showed an improvement in the implementation of the principles of corporate governance which is consistent with the stakeholder theory perspective. The basis for this improvement may be due to corporate governance reforms and new regulations that took place between 2003 and 2013.

The corporate firms in Nigeria have implemented the principles of shareholders' rights. However, the shareholders in corporate firms have the right to participate in firms' profits while details about the capital structure of firms were not fully disclosed. Shareholders also have the right to vote in general meetings but ownership transfer among shareholders was poorly facilitated; they also have the right to obtain information about voting rights before purchase of shares but minority shareholders were not fairly treated; the annual audits of the firms was conducted by an independent auditor but the financial and operating reports of the firms were not fully disclosed. Therefore, the study concludes that board of directors usually takes the interests of the shareholders more important than stakeholders' interest in the firms. It was however suggested that corporate governance framework in Nigeria should recognize the rights of stakeholders established by law or through mutual agreements; and encourage wealth creation and employment opportunities for sound financial sustainability of corporate firms. 


\section{References}

Aguilera, R.V, and Cuervo-Cazurra, A (2009). Codes of Good Governance, Corporate Governance: An International Review, Vol. 17, No. 3, pp. 376-387. https://doi.org/10.1111/j.1467-8683.2009.00737.x

Ahmed, E. and Hamdan, A. (2015). The Impact of Corporate Governance on Firm Performance: Evidence from Bahrain Bourse. International Management Review, 11(2), 21-37.

Al-Tamimi, $\mathrm{H}$ and Charif, $\mathrm{H}$ (2012). Corporate Governance Practices and the role of the Board of Directors: Evidence from UAE Conventional and Islamic Banks, Corporate Ownership and Control, Vol.10, No. 2, pp. 207-213.

Awotundun, D, Kehinde, J and Somoye, R (2011). Corporate Governance and Stakeholders Interest: A case of Nigerian Banks, International Journal of Business and Management, Vol. 6, No. 10, p. pp. $102-112$.

Berman, S.L, Wicks, A.C, Kotha, S and Jones, T.M (1999). Does Stakeholder Orientation Matter? the relationship between Stakeholder Management Models and Firm Financial Performance, Academy of Management Journal, Vol. 42, No. 5, pp. 488-506. https://doi.org/10.5465/256972

Chen, W.P, Chung, H, Lee, C and Liao, W.L (2007). Corporate Governance and Equity liquidity: Analysis of S\&P Transparency and Disclosure Rankings. Corporate Governance: An International Review, Vol. 15, No. 4, pp. 644-660.

Cheung, Y.L, Connelly, J.T, Jiang, P and Limpaphayom., P (2011). Does Corporate GovernancePredict Future Performance? Evidence from Hong Kong', Financial Management, Vol. 40, No. 1, pp. 159197.

Chhaochharia, V and Laeven, L (2009). Corporate Governance Norms and Practices, Journal of Financial Intermediation, Vol. 18, No. 3, pp. 405-431. https://doi.org/10.1016/j.jfi.2008.10.001

Comford, A (2004). Key Financial Codes and Standards: Different Views of their Role in a New Financial Architecture', Unpublished Paper prepared for the Multi-Stakeholder Consultations on Systemic Issues, Organized by the New Rules for Global Finance Coalition in cooperation with the United Nations Financing for Development Office.

De Andres, P, Azofra, V and Lopez, F (2005). Corporate Boards in OECD Countries: Size, Composition, Functioning and Effectiveness', Corporate Governance: An International Review, vol. 13, No. 2, pp. 197-210.

Doidge, C, Karolyi, G.A and Stulz, R.M (2004). Why Are Foreign Firms listed in the US Worth More, Journal of financial economics, Vol. 71, No. 2, pp. 205-238. https://doi.org/10.1016/S0304-405X(03)001831

Gill, A. (2009). CLSA Watch: Corporate Governance in the Emerging Markets. New York: CLSA CG.

Gillan, S.E and Starks, E.T (2000). Corporate Governance Proposals and Shareholder Activism: The Role of Institutional Investors, Journal of financial economics, Vol. 57, No. 2, pp. 275-305.

Givoly, D and Palmon, D (1985). Insider Trading and the Exploitation of Inside Information: Some Empirical Evidence, Journal of business, Vol. 58, No. 1, pp. 69-87. https://doi.org/10.1086/296283

Harabi, N (2007). State of Corporate Governance in Arab Countries: An overview, Munich Personal RePEC Archive, paper No. 4566, University of Applied Sciences, Northwestern Switzerland, 
Jang, H and Kim, J (2001). Korea Country Paper: The Role of Boards and Stakeholders in Corporate Governance. The Third OECD Asian Roundtable on Corporate Governance, Singapore, 4th $6^{\text {th }}$ April 2001, pp. 1-15, https://doi.org/10.1108/EUM0000000005490

Jesover, F and Kirkpatrick, G (2005). The Revised OECD Principles of Corporate Governance And Their Relevance to Non-OECD Countries, Corporate Governance: An International Review, Vol. 13, No. 2, pp. 127-136.

Karpoff, J.M., Malatesta, P.H and Walkling, R.A (1996). Corporate Governance and Shareholder Initiatives: Empirical Evidence, Journal of Financial economics, Vol. 42, No. 3, pp. 365-395.

Khaled, M.O (2014). Corporate Governance and Firm Performance in United Arab Emirate, College of Business, Victoria University of Melbourne Australia. Pp. 156-164

King, T-HD and Wen, M-M (2011). Shareholder Governance, Bondholder Governance, and Managerial Risk-Taking, Journal of Banking and Finance, Vol. 35, No. 3, pp. 512-531.

Klapper, L.F and Love, I (2004). Corporate Governance, Investor Protection, and Performance in Emerging Markets, Journal of corporate Finance, Vol. 10, No. 5, pp. 703-728. https://doi.org/10.1016/S09291199(03)00046-4

Magbagbeola, N.O. (2005). Governance Structure, Managerial Characteristics and Firm Performance in the Nigerian Banking Industry. Final Report Submitted to the AERC, South Africa (Dec).

Mak, Y. T., and Li, Y. (2001). Determinants of Corporate Ownership and Board Structure: Evidence from Singapore. Journal of Corporate Finance, 7(3), 235-256. https://doi.org/10.1016/S09291199(01)00021-9

Mak, Y., Kusnadi, Y. (2005). Size Really Matters: Further Evidence on the Negative Relationship between Board Size and Firm Value. Pacific-Basin Finance Journal, Vol. 13, pp. 301-318.

Mallin, C and Melis, A (2012). Shareholder Rights, Shareholder Voting, and Corporate Performance, Journal of Management and Governance, vol. 16, No. 2, pp. 171-176.

Morck, R., Shleifer, A., and Vishny, R. W. (1988). Management Ownership and Market Valuation: An Empirical Analysis", Journal of Financial Economics, 20(2), 293-315. https://doi.org/10.1016/0304405X(88)90048-7

Mulili, B.M \& Wong, P (2011). Corporate Governance Practices in Developing Countries: The Case for Kenya, International Journal of Business Administration, Vol. 2, No. 1, pp. 14-27. https://doi.org/10.5430/ijba.v2n1p14

Murphy, A and Topyan, K (2005). Corporate Governance: A Critical Survey of key Concepts, Issues, and Recent Reforms in the US, Employee Responsibilities and Rights Journal, Vol. 17, No. 2, pp. 75-89.

Nestor, S and Jesover, F (2000). OECD Principles of Corporate Governance on Shareholder Rights and Equitable Treatment: Their Relevance To The Russian Federation', 2nd OECD/World Bank Corporate Governance Roundtable for Russia, Moscow.

OECD (2004). OECD principles of corporate governance, OECD, Paris.

Okpara, J.O (2011). Corporate Governance in a Developing Economy: Barriers, Issues, and Implications for Firms, Corporate Governance, Vol. 11, No. 2, pp. 184-199. https://doi.org/10.1108/14720701111121056 
Prugsarnatz, N.C (2010). Corporate Governance Effects on Firm Value and Stock Market Performance: An Empirical Study of the Stock Exchange of Thailand-100-index listed companies, e- Journal, Vol. 3, no. 2, pp. 35-49.

Sengur, E.D (2011). Do Corporate Governance Index Companies Outperform Others? Evidence From Turkey. International Journal of Business and Social Science, Vol. 2, No. 14, pp. 254-260.

Shanikat, M and Abbadi, S.S (2011). Assessment of Corporate Governance in Jordan: An Empirical Study, Australian Accounting Business and Finance Journal, Vol. 5, No. 3; pp. 93-106.

Zikmund, W.G (2010). Business Research Methods, 8th edition, South-Western Cengage Learning, Mason, $\mathrm{OH}$. 